\title{
Protective immunity in juvenile coho salmon Oncorhynchus kisutch following immunization with Vibrio ordalii lipopolysaccharide or from exposure to live $V$. ordalii cells
}

\author{
M. I. Velji ${ }^{1}$, L. J. Albright ${ }^{1}$, T. P. T. Evelyn ${ }^{2}$ \\ ${ }^{1}$ Biological Sciences Department, Simon Fraser University, Burnaby, British Columbia, Canada V5A 1S6 \\ ${ }^{2}$ Department of Fisheries and Oceans, Pacific Biological Station, Nanaimo, British Columbia, Canada V9R 5K6
}

\begin{abstract}
Naive, juvenile coho salmon Oncorhynchus kisutch were protected against an experimental challenge with the fish pathogen Vibrio ordalii following vaccination with $V$. ordalii lipopolysaccharide (LPS) administered by either the intraperitoneal or immersion route. Purified LPS extracted from $V$. ordalii cell walls (CW-LPS) and semi-purified extracellular LPS from the broth used for growing $V$. ordalii cells (EC-LPS) resulted in protection by each of these routes. Amounts of CW-LPS as low as $100 \mathrm{pg}$ via the intraperitoneal route and $500 \mathrm{ng} \mathrm{ml}^{-1}$ via the immersion route were effective in protecting $4.8 \mathrm{~g}$ coho salmon against $V$. ordalii. Naive, juvenile coho salmon surviving bath exposure to live cells of $V$. ordalii also developed immunity to the pathogen. Exposure for 15 min to numbers of $V$. ordalii cells low enough not to cause vibriosis $\left(2.8 \times 10^{1}\right.$ to $\left.1.1 \times 10^{6}\right)$ resulted in measurable immunity to $V$ ordalii. These results are consistent with those obtained in this laboratory and elsewhere with the related but better studied fish pathogen $V$. anguillarum. We also document in quantitative terms, and for the first time, the extremely high level of immunogenicity associated with $V$, ordalii LPS.
\end{abstract}

\section{INTRODUCTION}

Vibrio vaccines have been used with considerable success in various parts of the world to protect salmonids farmed in seawater against losses due to vibriosis (Evelyn 1984, 1988). In British Columbia (B. C.), Canada, bacterins containing the 2 fish pathogenic vibrios indigenous to the region's coastal waters (Vibrio anguillarum $=V a$, and Vibrio ordalii $=V o$ ) have routinely been used for this purpose. Early work with vibrio bacterins in $\mathrm{B}$. C. indicated that their immunogenicity was due to a substance occurring in both the free and cell-associated form (Evelyn \& Ketcheson 1980). Initial evidence suggested that the immunogens were lipopolysaccharides (LPS): they were large, heat-stable molecules that were resistant to the harsh techniques used for their extraction and purification (reviewed by Evelyn 1984). Further, LPS was known to be a major surface antigen of $V a$ and $V o$ (Chart \& Trust 1984). Direct evidence that LPS was indeed the immunogen was obtained when purified LPS of Va (Kawai \& Kusuda 1983, Aoki et al. 1984, Salati et al. 1989) and of Vo (Evelyn \& Wong cited in Evelyn 1988) was successfully used to immunize salmonids against experimental challenge with $V a$ and $V o$, respectively.

In this study we focussed our attention on the less well studied Vo. Our purpose was, first, to determine how much Vo LPS was required to induce immunity in juvenile salmon when administered by intraperitoneal and immersion routes. This goal has important implications regarding the cost of vaccinating salmonids against vibriosis.

Our second goal was to determine whether exposure to live Vo cells would serve to immunize young salmon against subsequent challenges with the pathogen. Exposure to live $V a$ cells had already been found to protect young salmonids against $V a$ (Braaten \& Hodgins 1976, Egidius \& Andersen 1979, Evelyn \& Ketcheson 1980, Thorburn et al. 1987).

\section{MATERIALS AND METHODS}

Three experiments were conducted. The first 2 examined the efficacy of vaccinating juvenile coho salmon Oncorhynchus kisutch with various doses of Vo 
LPS administered by each of 2 methods: by intraperitoneal injection (IP) and by the immersion method (IMM). The third experiment examined the effect of exposing juvenile coho salmon to various concentrations of live $V o$ cells and the subsequent ability of the fish to resist an experimental challenge with live Vo.

Bacterium. The $V_{0}$ isolate (\#74/48) used in this study was obtained from a seawater-reared sockeye salmon Oncorhynchus nerka that had died of vibriosis in 1974 (Evelyn \& Ketcheson 1980). The isolate was typical of $V_{O}$ and has been described elsewhere (Schiewe et al. 1981).

LPS preparation and quantitation. When used as a source of cell wall-associated LPS (CW-LPS) or of extracellular LPS (EC-LPS), the isolate was grown at $22^{\circ} \mathrm{C}$ for $32 \mathrm{~h}$ in aerated Brain Heart Infusion Broth (Difco), supplemented with $1 \% \mathrm{NaCl}$. Growth was stopped by the addition of formalin to a final concentration of $0.5 \%(\mathrm{v} / \mathrm{v})$ and the formalin-treated culture was left overnight with stirring. The broth culture was then processed as follows to obtain the CW-LPS and EC-LPS. Vo cells were pelleted by centrifugation at $10400 \times g$ for $30 \mathrm{~min}$ at $4^{\circ} \mathrm{C}$ and washed twice with phosphate buffered saline (PBS $=0.15 \mathrm{M}, \mathrm{pH} 7.4$ ). CW-LPS was extracted from the cells by the method of Darveau \& Hancock (1983). The spent broth was centrifuged again and the supernatant collected. The supernatant was then diluted $1: 2$ with ultrafiltered (YM100 filter, Amicon Corp.) PBS and concentrated over a YM100 filter using a $200 \mathrm{ml}$ positive-pressure cell (Amicon Corp.). The retentate was washed thoroughly with PBS until the absorbance of the filtrate at $280 \mathrm{~nm}$ was the same as that of PBS. The retentate was then centrifuged at $50000 \times \mathrm{g}$ for $30 \mathrm{~min}$ to pellet any fine particles present. The supernatant was then ultracentrifuged at $200000 \times g$ for $2 \mathrm{~h}$ to pellet the semi-purified EC-LPS and then washed twice with Tris buffer $(0.01 \mathrm{M}, \mathrm{pH} 8.0)$. Both types of LPS were quantitated by the chromogenic limulus amoebocyte lysate method (M. A. Whittaker, Bio-products). The CW-LPS and EC-LPS were also characterized by sodium dodecyl sulfate polyacrylamide gel electrophoresis (Laemmli 1970), and by silver staining using the method of Tsai \& Frasch (1982) as modified by Hitchcock \& Brown (1983). These preparations were found to have silver-stained profiles similar to the cell wall LPS extract of Vo described by Chart and Trust (1984). We detected protein in the EC-LPS, but not in the CW-LPS, when the gels were loaded with 5 times the amount of material required for detecting LPS and were then stained with Coomasie blue. Protein levels in our LPS preparations were quantified using the Bradford-based protein assay (Bio-Rad). There was $1.2 \%$ protein in the CW-LPS and $2.6 \%$ protein in the EC-LPS.
Challenge suspensions. When the isolate was used as a live vaccine (Expt 3) or for challenging the various groups of vaccinated and control fish, it was grown for $42 \mathrm{~h}$ at $22^{\circ} \mathrm{C}$ on Tryptic Soy Agar (TSA; Difco), supplemented with $1 \% \mathrm{NaCl}$. The cells were then harvested and suspended in peptone $(0.1 \%)$-saline $(0.9 \%$ $\mathrm{NaCl}$ (PS). They were then diluted to a standard turbidity of 1.0 at $540 \mathrm{~nm}$, and further dilutions of this suspension were made in PS to obtain challenge suspensions of the desired strength and to permit counts of the existing viable cell population. The technique of Miles \& Misra (1938) was used for the latter purpose.

Fish and fish handling. The coho salmon used in the study were under-yearlings and averaged $4.8 \mathrm{~g}$ and $13.5 \mathrm{~g}$, depending on the experiment in which they were used. They were obtained from a local (the Big Qualicum River) stock and were reared in well water at the Department of Fisheries and Oceans Rosewall Creek facility, some $80 \mathrm{~km}$ north of our laboratory. The fish were transported to our laboratory at the Pacific Biological Station at least $10 \mathrm{~d}$ prior to use and were held in an $800 \mathrm{l}$ tank, supplied with flowing dechlorinated city water. During this period, fish were gradually acclimatized to a temperature of $13 \pm 1{ }^{\circ} \mathrm{C}$.

Vaccination procedures. In Expts 1 and 2, fish vaccinated by the IP route were first anesthetized with 2phenoxyethanol $(0.037 \% \mathrm{v} / \mathrm{v})$ to facilitate their handling and minimize stress. They were then injected with $0.1 \mathrm{ml}$ of sterile, pyrogen-free water (controls) or with $0.1 \mathrm{ml}$ of sterile, pyrogen-free water containing various test doses of LPS (see Tables 1 and 2 of the 'Results and Discussion' section for details). Fish immunized by immersion in Expts 1 and 2 were not anesthetized because anesthesia had been shown to reduce the uptake of a number of antigens (Evelyn 1984). These fish were immersed in 2.01 of aerated fish-culturewater (controls) or in $2.0 \mathrm{l}$ of aerated fish-culture-water containing the desired concentrations of LPS. Immersion was carried out at $13^{\circ} \mathrm{C}$ for 3 or $30 \mathrm{~min}$. In Expt 3 , fish were vaccinated without anesthesia by immersing them for $15 \mathrm{~min}$ in $2.0 \mathrm{l}$ of aerated PS (controls) or in 2.01 of aerated PS containing the desired concentrations of viable Vo cells at $13^{\circ} \mathrm{C}$ (see Table 3 of the Results and Discussion section for details). Two 25-fish lots of coho salmon were used for each treatment, except where otherwise specified, and the lots were held in separate 351 tanks, each of which was supplied with flowing dechlorinated city water at $13 \pm 1^{\circ} \mathrm{C}$. Following vaccination, fish were held for $21 \mathrm{~d}$ (Expts 1 and 2) or for 13 to $21 \mathrm{~d}$ (Expt 3) at 12 to $14^{\circ} \mathrm{C}$ and then challenged.

Challenge method. Challenge consisted of an IP injection containing $0.1 \mathrm{ml}$ of the $V_{0}$ cell suspension, described above. Challenged fish were monitored for mortalities for $14 \mathrm{~d}$, by which stage all mortalities 
appeared to have ceased. Kidney samples from $10 \%$ of the dead fish were cultured on TSA containing $1 \%$ added $\mathrm{NaCl}$ to verify that Vo was the cause of death. Identification of $V o$ growth on the plates was accomplished serologically (agglutination test) using a $V_{O}$ specific rabbit serum (Gibco).

Agglutination titers. Blood samples were collected from the severed caudal peduncles of anesthetized fish in heparinized Caraway tubes. Five fish were sampled prior to vaccination, and 10 fish per treatment (5 fish per tank) were sampled just prior to challenge. The blood was centrifuged and the resulting plasma samples titrated for their Vo agglutinin levels using routine procedures in microtiter plates and formalin-killed $V o$ cells.

Statistical analysis. Mortalities in the various replicate groups of fish were pooled (to give deaths per 30 or $40 \mathrm{fish}$ ) and the pooled data for the treated and control fish were compared using the Tukey test for multiple comparisons of proportions (Zar 1984). The probability that the observed mortalities were significantly different was taken as $\mathrm{p}<0.05$. Relative percentage survival (RPS) was calculated according to the formula suggested by Amend (1981).

\section{RESULTS AND DISCUSSION}

It has been shown by Evelyn \& Wong (cited in Evelyn 1988) that coho salmon Oncorhynchus kisutch immunized with $10 \mu \mathrm{g}$ of Vo LPS via the IP route, or with $10 \mu \mathrm{g} \mathrm{ml} \mathrm{m}^{-1}$ of LPS via the IMM method, demonstrated protective immunity towards Vo when experimentally challenged. In the present experiment, both the pure CW-LPS and semi-purified EC-LPS were found to elicit protective immunity in juvenile coho salmon, by either the IP or IMM mode of immunization (Table 1). The level of challenge used in this experiment was low and resulted in mortalities similar to those observed in pen-cultured salmonids (Evelyn unpubl. data). Protective immunity in coho vaccinated by IMM declined with decreasing concentrations of EC-LPS, the lowest dose eliciting immunity lying between 1 and $100 \mathrm{ng} \mathrm{ml}^{-1}$. With IP immunization, solid protection was found in coho that received the lowest dose of EC-LPS tested (1 ng). The latter observation suggested that doses of LPS below $1 \mathrm{ng}$ fish $^{-1}$ are immunogenic.

The second experiment was undertaken to investigate the lowest doses of LPS required to induce immunity via the IP and IMM methods under conditions of a strenuous challenge. For IP immunization, the lower limit of LPS required to yield protective immunity was again not determined because even the lowest dose tested (100 pg/4.8 g fish) was sufficient to result in almost complete protection (Table 2). This dose was equivalent to approximately $20 \mathrm{ng}$ LPS $\mathrm{kg}^{-1}$ fish. With the IMM method, we found $500 \mathrm{ng} \mathrm{m}^{-1}$ to $1 \mu \mathrm{g} \mathrm{ml}^{-1}$ of LPS resulted in essentially complete protection in fish immersed for either 3 or $30 \mathrm{~min}$. Therefore, at these concentrations of LPS, extending the time of immersion from 3 to 30 min was not useful. However, at the lowest concentration of LPS tested (10 $\left.\mathrm{ng} \mathrm{ml}^{-1}\right)$, extending the time of immersion resulted in higher levels of survival. These results suggest that when the vaccine is very dilute, better protection will be achieved by extending the immersion time. In summary, the findings indicate that very small amounts of Vo LPS (ca $20 \mathrm{ng} \mathrm{kg}^{-1}$ fish) are sufficient to induce virtually complete protection (RPS $85 \%$ ) in coho salmon via the IP route. The concen-

Table 1. Oncorhynchus kisutch. Immunization of coho salmon with various forms of Vibrio ordalii (Vo) lipopolysaccharide (LPS). Experiment carried out at 12 to $14^{\circ} \mathrm{C}$ with fish averaging $13.7 \mathrm{~g}$; fish were challenged intraperitoneally with $1.1 \times 10^{5}$ viable Vo cells $21 \mathrm{~d}$ post-vaccination; ensuing mortalities were monitored for $14 \mathrm{~d}$. Abbreviations are: (EC and $\mathrm{CW}$ ): extracellular and whole cell, respectively; (t1/t2): tanks 1 and 2; (RPS): relative percentage survival. Proportion of mortalities followed by different letters are significantly different at $\mathrm{p}<0.05$ for the specified method of vaccination

\begin{tabular}{|c|c|c|c|c|c|c|}
\hline \multirow[t]{2}{*}{ Method } & \multicolumn{2}{|c|}{ LPS } & \multirow{2}{*}{$\begin{array}{l}\text { No. dead tank } \\
\qquad(\mathrm{t} 1 / \mathrm{t} 2)\end{array}$} & \multirow{2}{*}{$\begin{array}{l}\text { Total no. dead/ } \\
\text { no. challenged }\end{array}$} & \multirow{2}{*}{$\begin{array}{c}\text { Total dead } \\
(\%)\end{array}$} & \multirow{2}{*}{$\begin{array}{l}\text { RPS } \\
(\%)\end{array}$} \\
\hline & Form & Dose & & & & \\
\hline \multirow{5}{*}{$\begin{array}{l}\text { Intraperitoneal } \\
\text { injection }\end{array}$} & Control & & $2 / 8$ & $10 / 40^{a}$ & 25.0 & 0.0 \\
\hline & EC-LPS & $1 \mathrm{ng}$ & $0 / 0$ & $0 / 40^{\mathrm{b}}$ & 0.0 & 100.0 \\
\hline & EC-LPS & $100 \mathrm{ng}$ & $0 / 0$ & $0 / 40^{b}$ & 0.0 & 100.0 \\
\hline & EC-LPS & $500 \mathrm{ng}$ & $0 / 0$ & $0 / 40^{b}$ & 0.0 & 100.0 \\
\hline & CW-LPS & $500 \mathrm{ng}$ & $0 / 0$ & $0 / 40^{b}$ & 0.0 & 100.0 \\
\hline \multirow[t]{6}{*}{ Inmersion } & Control & & $9 / 8$ & $17 / 40^{a}$ & 42.5 & 0.0 \\
\hline & EC-LPS & $1 \mathrm{ng} \mathrm{ml}^{-1}$ & $3 / 9$ & $12 / 40^{\mathrm{a}}$ & 30.0 & 29.4 \\
\hline & EC-LPS & $100 \mathrm{ng} \mathrm{ml}^{-1}$ & $1 / 1$ & $2 / 40^{b}$ & 5.0 & 88.3 \\
\hline & EC-LPS & $500 \mathrm{ng} \mathrm{ml}^{-1}$ & $0 / 0$ & $0 / 40^{b}$ & 0.0 & 100.0 \\
\hline & EC-LPS & $1 \mu \mathrm{g} \mathrm{ml}^{-1}$ & $0 / 0$ & $0 / 40^{b}$ & 0.0 & 100.0 \\
\hline & CW-LPS & $1 \mu \mathrm{g} \mathrm{ml}^{-1}$ & $0 / 0$ & $0 / 40^{\mathrm{b}}$ & 0.0 & 100.0 \\
\hline
\end{tabular}


Table 2. Oncorhynchus kisutch. Immunization of coho salmon with Vibrio ordalii (Vo) extracellular lipopolysaccharide (EC-LPS). Experiment carried out at 12 to $14{ }^{\circ} \mathrm{C}$ with fish averaging $4.8 \mathrm{~g}$; fish were challenged intraperitoneally with $1.3 \times 10^{5}$ viable Vo cells $21 \mathrm{~d}$ post-vaccination; ensuing mortalities were monitored for $14 \mathrm{~d}$. See Table 1 for further details

\begin{tabular}{|c|c|c|c|c|c|}
\hline Method & Dose & $\begin{array}{l}\text { No. dead tank } k^{-1} \\
\qquad(\mathrm{t} 1 / \mathrm{t} 2)\end{array}$ & $\begin{array}{l}\text { Total no. dead/ } \\
\text { no. challenged }\end{array}$ & $\begin{array}{c}\text { Total dead } \\
\qquad(\%)\end{array}$ & $\begin{array}{l}\text { RPS } \\
(\%)\end{array}$ \\
\hline $\begin{array}{l}\text { Intraperitoneal } \\
\text { injection }\end{array}$ & $\begin{array}{l}\text { Control } \\
100 \mathrm{pg} \\
500 \mathrm{pg} \\
1 \mathrm{ng} \\
100 \mathrm{ng}\end{array}$ & $\begin{array}{c}20 / 13 \\
2 / 3 \\
0 / 0 \\
0 / 1 \\
0 / 0\end{array}$ & $\begin{array}{l}33 / 40^{\mathrm{d}} \\
5 / 40^{\mathrm{b}} \\
0 / 40^{\mathrm{c}} \\
1 / 40^{\mathrm{c}} \\
0 / 40^{\mathrm{c}}\end{array}$ & $\begin{array}{r}82.5 \\
12.5 \\
0.0 \\
2.5 \\
0.0\end{array}$ & $\begin{array}{r}0.0 \\
84.9 \\
100.0 \\
96.9 \\
100.0\end{array}$ \\
\hline Immersion (3 min) & $\begin{array}{l}\text { Control } \\
10 \mathrm{ng} \mathrm{ml}^{-1} \\
100 \mathrm{ng} \mathrm{ml}^{-1} \\
500 \mathrm{ng} \mathrm{ml}^{-1} \\
1 \mu \mathrm{g} \mathrm{ml}\end{array}$ & $\begin{array}{l}16 /{ }^{\circ} \\
16 / 12 \\
8 / 6 \\
1 / 1 \\
3 / 1\end{array}$ & $\begin{array}{r}16 / 20^{\mathrm{a}} \\
28 / 40^{\mathrm{a}} \\
14 / 40^{\mathrm{b}} \\
2 / 40^{\mathrm{c}} \\
4 / 40^{\mathrm{c}}\end{array}$ & $\begin{array}{r}80.0 \\
70.0 \\
35.0 \\
5.0 \\
10.0\end{array}$ & $\begin{array}{r}0.0 \\
12.5 \\
56.3 \\
93.8 \\
87.5\end{array}$ \\
\hline Immersion (30 min) & $\begin{array}{l}\text { Control } \\
100 \mathrm{ng} \mathrm{ml}^{-1} \\
100 \mathrm{ng} \mathrm{ml}^{-1} \\
500 \mathrm{ng} \mathrm{mi}^{-1} \\
1 \mu \mathrm{g} \mathrm{ml}\end{array}$ & $\begin{array}{r}11 / \\
3 / 7 \\
4 / 5 \\
0 / 0 \\
0 / 0\end{array}$ & $\begin{array}{c}11 / 20^{\mathrm{a}} \\
10 / 40^{\mathrm{b}} \\
9 / 40^{\mathrm{b}} \\
0 / 40^{\mathrm{c}} \\
0 / 40^{\mathrm{c}}\end{array}$ & $\begin{array}{r}55.0 \\
25.0 \\
22.5 \\
0.0 \\
0.0\end{array}$ & $\begin{array}{r}0.0 \\
54.5 \\
59.1 \\
100.0 \\
100.0\end{array}$ \\
\hline
\end{tabular}

tration of Vo LPS resulting in a similar level of protection via the IMM route was $500 \mathrm{ng} \mathrm{ml}^{-1}$, irrespective of the immersion time.

The high immunogenicity shown with Vo LPS is consistent with that found for $V a$ LPS by Aoki et al. (1984). They showed that Va LPS in amounts as low as $10 \mathrm{ng} \mathrm{m} \mathrm{m}^{-1}$ elicited immunity to $V a$ when immersionadministered, a finding that was presaged by the earlier studies of Croy \& Amend (1977) who established that crude $V a$ preparations could be highly diluted and still result in immunity to $V a$.

No agglutinating antibody titer was detected in any of the samples prior to vaccination or just prior to challenge. The failure to detect agglutinins in our fish following vaccination was not surprising because the amount of LPS administered by injection was small (1 $\mu \mathrm{g}$ fish $^{-1}$ or less) and because vaccination by immersion usually fails to elicit detectable Va agglutinins (Aoki et al. 1974, Croy \& Amend 1977, Kawano et al. 1984, Sakai et al. 1984). Notwithstanding this, and as will be reported in a separate communication, the plasma from the Vo LPS-vaccinated coho salmon (unlike that from the unvaccinated controls) contained Vo-specific antibodies because it could be used in passive immunization experiments to protect naive coho salmon from challenge with $V o$ and because this protection could be abrogated by absorbing the plasma with Vo cells but not with cells of a serologically unrelated fish pathogen Renibacterium salmoninarum. These facts clearly indicate that the anti-Vo protection resulting from vaccination with Vo LPS was due to a specific immune response.
Exposure of naive juvenile coho to bath challenge with levels of $V o$ cells insufficient to induce vibriosis, resulted in protective immunity (Table 3 ). Live Vo cells in concentrations as low as $2.8 \times 10^{1} \mathrm{ml}^{-1}$ resulted in significant protection when only a moderate level of IP challenge was used (42.5\% mortalities in controls). This level of protection was enhanced when the concentration of $V o$ cells in the initial exposure was increased by 100 -fold. When the initial concentration

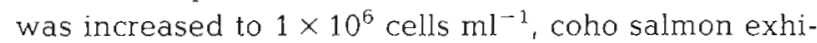
bited solid protection even when the challenge applied was severe enough to kill $90 \%$ of controls.

The above findings suggest that in farmed salmonids, natural challenge with Vo cells, at concentrations low enough not to cause disease, will serve to induce immunity against the pathogen and perpetuate the protective effect of an earlier vaccination. Under natural conditions, however, we surmise that a repeated presence of the pathogen on the farm will be required to ensure that a significant proportion of the fish is immunized because it seems probable that only a small proportion of the fish would come in contact with the pathogen during each of its appearances on the farm. Exposure to live Va cells has also been found to induce immunity in other salmonids (Braaten \& Hodgins 1976, Egidius \& Andersen 1979, Evelyn \& Ketcheson 1980, Thorburn et al. 1987) but, as Thorburn et al. (1987) have suggested, the value of natural challenge with Vamay often be reduced because of the farmers' tendency to terminate infections by early interventions using chemotherapy.

Vo-induced immunity obtained in this study was almost certainly elicited by LPS because the LPS prepa- 
Table 3. Oncorhynchus kisutch. Immunization of coho salmon by bath exposure to live Vibrio ordalii (Vo) cells: effect of Vo cell concentration on degree of protection. Experiments carried out at 12 to $14{ }^{\circ} \mathrm{C}$ with fish averaging $13.5 \mathrm{~g}$; none of the fish exposed to live $V o$ by immersion died or developed signs of vibriosis; they were then challenged intraperitoneally (IP) at indicated times post-exposure with indicated dosages of Vo cells; ensuing mortalities were monitored for $14 \mathrm{~d}$. See Table 1 for further details

\begin{tabular}{|c|c|c|c|c|c|c|}
\hline $\begin{array}{l}\text { Vo immersion } \\
\text { dose (cells } \mathrm{ml}^{-1} \text { ) }\end{array}$ & $\begin{array}{l}\text { No. d prior to } \\
\text { challenge }\end{array}$ & $\begin{array}{c}\text { IP challenge } \\
\text { (no. Vo cells fish } \\
\text { (n) }\end{array}$ & $\begin{array}{l}\text { No. dead tank } k^{-1} \\
(\mathrm{t} 1 / \mathrm{t} 2)\end{array}$ & $\begin{array}{l}\text { Total no. dead/ } \\
\text { no. challenged }\end{array}$ & $\begin{array}{l}\text { Total dead } \\
\qquad \%)\end{array}$ & $\begin{array}{l}\text { RPS } \\
(\%)\end{array}$ \\
\hline Control & 21 & $1.1 \times 10^{5}$ & $8 / 9$ & $17 / 40^{\circ}$ & 42.5 & 0.0 \\
\hline $2.8 \times 10^{1}$ & 21 & $1.1 \times 10^{5}$ & $4 / 4$ & $8 / 40^{b}$ & 20.0 & 52.9 \\
\hline $2.8 \times 10^{3}$ & 21 & $1.1 \times 10^{5}$ & $0 / 0$ & $0 / 40^{c}$ & 0.0 & 100.0 \\
\hline Control & 13 & $1.2 \times 10^{5}$ & $15 / 12$ & $27 / 30^{a}$ & 90.0 & 0.0 \\
\hline $1.1 \times 10^{6}$ & 13 & $1.2 \times 10^{5}$ & $0 / 0$ & $0 / 40^{\mathrm{b}}$ & 0.0 & 100.0 \\
\hline
\end{tabular}

rations tested contained only small amounts of other detectable antigens (1.2 to $2.6 \%$ protein). The quantities of LPS required to induce immunity were low, suggesting that the cost of producing anti-Vo vaccines should not be prohibitive. The $V o$ findings obtained here parallel those reported for the better studied $V a$, in that immunity to vibriosis could be induced by LPS or by live cells and in that strong immunity could occur in the absence of detectable humoral agglutinins. Whether these observations would hold true for Vibrio salmonicida, another important pathogen of salmonids farmed in seawater, remains to be seen.

Acknowledgements. We thank J. E. Ketcheson, L. ProsperiPorta and L. Needham for the excellent technical assistance provided at the Pacific Biological Station, E. Bassily from the Mathematics and Statistics Department, at Simon Fraser University for assistance with the statistical analyses, and Y. Jiwani for reading and typing the manuscript. This research was partially supported by an operating grant to LJA by the National Sciences and Engineering Research Council of Canada.

\section{LITERATURE CITED}

Amend, D. F. (1981). Potency testing of fish vaccines. Dev. biol. Stand. 49: 447-454

Aoki, T., Sakai, M., Takahashi, S. (1984). Protective immunity in Ayu, Plecoglossus altivelis, vaccinated by immersion with Vibrio anguillarum. Fish. Path. 19: 181-185

Braaten, A. B., Hodgins, H. O. (1976). Protection of steelhead trout (Salmo gairdneri) against vibriosis with a living lowvirulence strain of Vibrio anguillarum. J. Fish. Res. Bd Can. 33: 845-847

Chart, H., Trust, T. J. (1984). Characterization of the surface antigens of the marine fish pathogens Vibrio anguillarum and Vibrio ordalii. Can. J. Microbiol. 30: 703-710

Croy, T. R., Amend, D. F. (1977). Immunization of sockeye salmon (Oncorhynchus nerka) against vibriosis using the hyperosmotic infiltration technique. Aquaculture 12: 317-325

Darveau, R. P., Hancock, R. E. W. (1983). Procedure for isolation of bacterial lipopolysaccharides from both smooth and rough Pseudomonas aeruginosa and Salmonella typhimurium strains. J. Bact. 155: 831-838
Egidius, E. C., Andersen, K. (1979). Bath-immunization - a practical and non-stressing method of vaccinating sea farmed rainbow trout Salmo gairdneri against vibriosis. J. Fish Dis. 2: 405-410

Evelyn, T. P. T. (1984). Immunization against pathogenic vibrios. In: de Kinkelin, P., Michel, C. (eds.) Symposium on fish vaccination. O. I. E. Fish Diseases Commission, Paris

Evelyn, T. P. T. (1988). Vibrio vaccines for salmonids. In: Aquaculture int. Congr. Expo Proc., Vancouver, p. 459-469

Evelyn, T. P. T., Ketcheson, J. E. (1980). Laboratory and field observations on antivibriosis vaccines. In: Ahne, W. (ed.) Fish diseases, 3rd COPRAQ session. Springer-Verlag, Berlin, Heidelberg, New York, p. 45-52

Hitchcock, P. J., Brown, T. M. (1983). Morphological heterogeneity among salmonella lipopolysaccharide chemotypes in silver-stained polyacrylamide gels. J. Bact. 154: 129-277

Kawai, K., Kusuda, R. (1983). Efficacy of the lipopolysaccharide vaccine against vibriosis in cultured ayu. Bull. Jap. Soc. scient. Fish. 49: 511-514

Kawano, K., Aoki, T., Kitao, T. (1984). Duration of protection against vibriosis in ayu (Pecoglossus altivelis) vaccinated by immersion and oral administration with Vibrio anguillarum. Bull. Jap. Soc. scient. Fish. 50: 771-774

Laemmli, U. K. (1970). Cleavage of structural proteins during the assembly of head bacteriophage T4. Nature, Lond. 227: $680-685$

Miles, A. A., Misra, S. S. (1938). The estimation of the bacteriocidal power of blood. J. Hyg. 38: 732-749

Sakai, M., Aoki, T., Kitao, T., Rohovec, J. S., Fryer, J. L. (1984). Comparisons of the cellular immune response of fish vaccinated by immersion and injection of Vibrio anguillarum. Bull. Jap. Soc. scient. Fish. 50: 1187-1192

Salati, F., Watanabe, K., Kawai, K, Kusuda, R. (1989). Immune response of ayu against Vibrio anguillarum lipopolysaccharide. Nippon Suisan Gakk. 55: 45-49

Schiewe, M. H., Trust, T. J., Crosa, J. H. (1981). Vibrio ordalii sp. nov.: a causative agent of vibriosis in fish. Curr, Microbiol. 6: 343-348

Thorburn, M. A., Carpenter, T. E., Ljungberg, O. (1987). Effects of immersion in live Vibrio anguillarum and simultaneous oxytetracycline treatment on protection of vaccinated and non-vaccinated rainbow trout Salmo gairdneri against vibriosis. Dis. aquat. Org. 2: 167-171

Tsai, C.-M., Frasch, C. E. (1982). A sensitive silver stain for detecting lipopolysaccharide in polyacrylamide gels. Analyt. Biochem. 119: 115-119

Zar, J. H. (1984). Biostatistical analysis. Prentice-Hall, Englewood Cliffs, New Jersey

Manuscript first received: February 26, 1990

Revised version accepted: May 3, 1990 